\title{
Epidemiology of snakebite accidents in the municipalities of the state of Paraíba, Brazil
}

\author{
Epidemiologia dos acidentes ofídicos \\ ocorridos nos municípios do Estado da Paraíba, Brasil
}

Renner de Souza Leite ${ }^{1}$

Isabely Tamarys Gomes Targino ${ }^{1}$

Ysabel Arianne Cordeiro Ferreira Lopes ${ }^{1}$

Rafaella Moreno Barros ${ }^{1}$

Alecxandro Alves Vieira ${ }^{1}$

${ }^{1}$ Unidade Acadêmica de Saúde, Centro de Educação e Saúde, Universidade Federal de Campina Grande. Olho D'água da Bica s/n. 58175-000 Cuité PB. rennerleite@yahoo.com.br
Abstract Accidents involving venomous animals represent an important, albeit neglected, public health issue worldwide. A descriptive study was made of snakebite cases attended and recorded between 2007 and 2010 in the health units of the municipalities of Cariri, State of Paraiba, northeastern Brazil. Data was collected from the Injury Notification Information System data banks of the Health Ministry and a total of 351 records of snakebite victims were reviewed. Victims were predominantly male farm workers over 50. The highest incidence of snakebites occurred in rural areas, between April and June of 2007 and 2010. Snakes of the genus Bothrops were responsible for most cases, and victims were mostly bitten on the feet. The majority of the victims received medical assistance within 1 to 3 hours after being bitten. The most common clinical manifestations were pain, edema and ecchymosis, which were mainly classified as mild or moderate. Two deaths were reported. It was concluded that there is a significant impact of seasonality in snakebites, the prevalence of attacks caused by Bothrops, affecting the lower limbs of adult male farmers in rural areas. The findings of this study may contribute to identify the conditions that increase the risk of snake attacks in the northeastern region.

Key words Paraiba State, Venomous snakes, Human poisoning, Snakebite accidents, Epidemiology
Resumo Acidentes por animais peçonhentos representam um importante, embora negligenciado, problema de saúde pública mundial. Neste sentido, foi realizado um estudo descritivo dos acidentes ofídicos atendidos e registrados, entre 2007 e 2010, nas unidades de saúde dos municípios do Cariri, Estado da Paraíba, Nordeste do Brasil. As informações foram coletadas do banco de dados do Sistema de Informação de Agravos de Notificação do Ministério da Saúde. Um total de 351 registros de vítimas de ataques por serpentes peçonhentas foram analisados. As vitimas foram predominantemente trabalhadores rurais do sexo masculino com mais de 50 anos. As maiores incidências de acidentes ofídicos ocorreram em áreas rurais, entre abril e junho de 2007 e 2010. As serpentes do gênero Bothrops foram responsáveis pela maioria dos casos, e as vítimas foram, em sua maioria, picado nos pés. A maioria das vítimas recebeu assistência médica no prazo de 1 h a $3 \mathrm{~h}$ após a picada. As manifestações clinicas mais comuns foram dor, edema e equimoses, classificadas como leve ou moderada. Duas mortes foram relatadas. Os resultados deste estudo podem contribuir para identificar as condições que aumentam o risco dos acidentes ofídicos na Região Nordeste. Palavras-chave Paraíba, Serpentes peçonhentas, Envenenamento humano, Acidente ofídico, Epidemiologia 


\section{Introduction}

Snakebite envenomations represent a worldwide public health problem due to their high incidence, the seriousness and sequelae of the bite injuries, and the fatality rate ${ }^{1,2}$. Brazil has the highest number of poisonous snake attacks in South America, with 20,000 cases reported every year and a case fatality rate of $0.45 \%{ }^{3}$. In an effort to improve treatments of these victims, in 1986 it became obligatory to notify the Brazilian Health Ministry of all incidents involving poisonous animals. Nevertheless, questions related to epidemiological research, access to treatment, and training of health workers have been largely left out of national public policies ${ }^{4,5}$. Epidemiological studies have revealed that, in Brazil, most snakebite victims are males, farm workers, aged between 15 and 49 years, and that they are predominantly bitten on the feet and hands. Snakes of the genus Bothrops have shown to be responsible for the majority of snakebite cases. Attacks by snakes of the genus Crotalus are less frequent, while attacks by Lachesis and Micrurus are rare $^{6}$. The northeastern region has $43 \%$ of the snakes of medical importance in Brazil $^{7}$, with 25 species being identified so far, including 12 of the genus Bothrops (B. atrox, B. brazili, B. erythromelas, B. jararaca, B. jararacussu, B. leucurus, B. lutzi, B. marajoensis, B. moojeni, B. muriciensis, B. neuwiedi and B. pirajai), nine Micrurus (M. brasiliensis, M. corallinus, $M$. filiformis, $M$. hemprichii, $M$. ibiboboca, M. leminiscatus, M. psyches, M. surinamensis and M. spixii), two Bothriopsis (B. bilineata and B. taeniata), Crotalus durissus, and Lachesis muta. Three species of the family Colubridae was also identified. The most widely distributed species is the Crotalus durissus, which is found in all the northeastern states. Bothrops erythromelas and Bothrops leucurus are found in most of the northeastern region, with the exception of the states of Maranhão and Piauí, respectively ${ }^{7}$.

The Northeast is the region with the lowest incidence of poisonous snake attacks ( 7.65 cases/ 100,000 inhabitants); however, it has the highest case fatality rate related to these incidents $(0.81 \%$, approximately double the national average of $0.45 \%)^{8}$. In the state of Paraíba, the incidence of snakebites ( 9.53 cases/100,000 inhabitants) is lower than the national average (13.9 cases/100,000 inhabitants), but still higher than the average for the northeastern region (7.65 cases/100,000 inhabitants). In spite of a number of previous investigations $s^{7,9,10}$, the epidemiology of snakebites in the northeastern Brazil is not yet well understood, especially in light of the social and envi- ronmental changes that have occurred there in recent decades. In this sense, the current study analyzed the clinical and epidemiological profile of the snakebite cases reported from 2007 to 2010 in the municipalities of the Cariri region, located in the state of Paraíba, northeastern Brazil.

\section{Materials and Methods}

\section{Study area}

The state of Paraíba covers an area of 56,372 $\mathrm{km}^{2}$, and $98 \%$ of its territory is located within the "Drought Polygon", which is an area subjected to a prolonged period of drought ${ }^{11}$. The Cariri region is located in the central-southern part of this state and covers $11,192 \mathrm{~km}^{2}{ }^{12}$. This region has a population of about 185,235 inhabitants ${ }^{12}$, and the regional municipalities are small and have low population densities. Almost the entire region has low rainfall rate, high average temperatures, acute water deficits, generally thin and often salty soils, and hyperxerophytic caatinga vegetation. Increased environmental degradation, observed in all Cariri region, have contributed to the development of desertification processes and, consequently, to the reduction of natural habitats for snakes.

\section{Data collection}

A retrospective descriptive study of the clinical-epidemiological characteristics of snakebites in the Cariri region was carried out. Epidemiological investigation was based on snakebite cases reported from 2007 to 2010 for the 29 municipalities of this region (see Table 1). Data was collected from the Second Health Sector of Monteiro and the Third Health Sector of Campina Grande, using the SINAN (Injury Notification Information System) data banks of the Health Ministry. It was excluded 17 patients, which not having age or date of birth registered in the notification files. This research followed all the ethical principles in accordance with Declaration of Helsinki. Epidemiological data was analyzed in relation to the sex and age of the victims, year and month of the snake attack, zone of occurrence (urban or rural), genus of the snake, part of the body bitten, and time elapsed between accident and medical assistance. The variables investigated in the clinical evaluations were: local and systemic clinical manifestations, seriousness and evolution of the case, and serotherapy. As 
Table 1. Descriptive analyses of snakebite cases registered in the Cariri region, State of Paraíba, Brazil, from 2007 to 2010 , according to quantitative demographic variables $(\mathrm{n}=351)$.

\begin{tabular}{|c|c|c|c|c|c|}
\hline \multirow{2}{*}{ Variables } & \multicolumn{4}{|c|}{ Year } & \multirow[b]{2}{*}{ Total } \\
\hline & 2007 & 2008 & 2009 & 2010 & \\
\hline \multicolumn{6}{|l|}{ Seasonality per trimester } \\
\hline $1^{\text {st }}$ trimester & 22 & 21 & 13 & 29 & 85 \\
\hline $2^{\text {nd }}$ trimester & 27 & 14 & 32 & 42 & $115^{*}$ \\
\hline $3^{\text {rd }}$ trimester & 28 & 18 & 29 & 14 & 89 \\
\hline $4^{\text {th }}$ trimester & 18 & 19 & 11 & 14 & 62 \\
\hline \multicolumn{6}{|l|}{ Municipality } \\
\hline Alcantil & 0 & 0 & 0 & 0 & 0 \\
\hline Amparo & 4 & 3 & 3 & 2 & 12 \\
\hline Assunção & 0 & 0 & 0 & 0 & 0 \\
\hline Barra de Santana & 2 & 6 & 3 & 2 & 13 \\
\hline Barra de São Miguel & 4 & 1 & 2 & 0 & 7 \\
\hline Boqueirão & 2 & 1 & 0 & 0 & 3 \\
\hline Cabaceiras & 1 & 0 & 0 & 0 & 1 \\
\hline Camalaú & 3 & 6 & 7 & 4 & 20 \\
\hline Caraúbas & 3 & 5 & 1 & 1 & 10 \\
\hline Caturité & 0 & 0 & 0 & 0 & 0 \\
\hline Congo & 2 & 4 & 5 & 5 & 16 \\
\hline Coxixola & 2 & 3 & 1 & 3 & 9 \\
\hline Gurjão & 3 & 1 & 1 & 1 & 6 \\
\hline Livramento & 2 & 0 & 0 & 0 & 2 \\
\hline Monteiro & 9 & 10 & 18 & 30 & 67 \\
\hline Ouro Velho & 0 & 0 & 3 & 2 & 5 \\
\hline Parari & 6 & 3 & 1 & 1 & 11 \\
\hline Prata & 0 & 1 & 2 & 7 & 10 \\
\hline Riacho de Santo Antônio & 4 & 1 & 0 & 2 & 7 \\
\hline Santo André & 4 & 5 & 0 & 0 & 9 \\
\hline São Domingos do Cariri & 1 & 1 & 1 & 1 & 4 \\
\hline São João do Cariri & 4 & 2 & 1 & 4 & 11 \\
\hline São João do Tigre & 0 & 1 & 2 & 4 & 7 \\
\hline São José dos Cordeiros & 7 & 2 & 4 & 2 & 15 \\
\hline São Sebastião do Umbuzeiro & 0 & 1 & 3 & 3 & 7 \\
\hline Serra Branca & 15 & 4 & 10 & 4 & 33 \\
\hline Sumé & 5 & 9 & 11 & 15 & 40 \\
\hline Taperoá & 12 & 2 & 3 & 3 & 20 \\
\hline Zabelê & 0 & 0 & 3 & 3 & 6 \\
\hline \multicolumn{6}{|l|}{ Localities of Occurrence } \\
\hline Urban & 19 & 13 & 19 & 18 & 69 \\
\hline Rural & 74 & 58 & 64 & 79 & 275 \\
\hline Unknown & 2 & 1 & 2 & 2 & 7 \\
\hline Total number of cases & 95 & 72 & 85 & 99 & 351 \\
\hline
\end{tabular}

" $\mathrm{p}<0.05$ significant when compared to the snakebite cases occurred in the fourth trimester (Tukey Test). No significant difference was observed when compared to the snakebite cases occurred in the second semester with the first and third ones (Tukey Test).

regards the genus of the offending snakes, the data obtained was based on information given by the patients themselves and/or their companions, as well as on the clinical observation by health professionals of the patients' signs and symptoms. Therefore, in the medical records analyzed in this study, the identification of the offending snake was not performed by experts.
The incidence of snakebites for the Cariri region was calculated for the period from 2007 to 2010 . Demographic and population data furnished by the Brazilian Institute of Geography and Statistics (IBGE) $)^{13}$ were used to calculate incidence rates. Statistical analyses were performed using the Analysis of Variance (one-way ANOVA), the Chisquare (Likelihood Ratio Chi-Square) and the 
Tukey tests. The level of significance was set at $\mathrm{P}$ $<0.05$. All statistical analyses were performed using the software SPSS ${ }^{\oplus}$ version 13.0 (Statistical Package for Social Sciences) for Windows.

\section{Results}

A total of 351 snakebite cases were notified in the Cariri region between January/2007 and December/2010, with incidence rate of 52 cases/100,000 inhabitants in 2007, 62 cases/100,000 inhabitants in 2008, 48 cases/100,000 inhabitants in 2009 and 34 cases/100,000 inhabitants in 2010. Table 1 shows the snakebite data in terms of quantitative-demographic variables. Snake attacks occurred during all months of the year, with the largest number of cases being reported in the second trimester $(\mathrm{n}=115 ; 32.8 \%)$ and the smallest number in the fourth trimester $(n=62 ; 17.7 \%)$. Frequency of attacks was significantly higher in the second trimester when compared with the fourth trimester $(p<0.05)$. No significant differences were observed when comparing the second semester with the first and third ones. The highest frequency of attacks was observed in the municipality of Monteiro $(n=67 ; 19.1 \%)$, and the lowest frequencies, in Cabaceiras $(\mathrm{n}=1 ; 0.3 \%)$ and Caturité $(\mathrm{n}=1 ; 0.3 \%)$. No snakebites were registered in the municipalities of Alcantil or Assunção during the period studied. Attacks mostly occurred in rural areas $(\mathrm{n}=275 ; 78.3 \%)$. Table 2 shows the individual characterization and circumstances of the reported snakebite cases. Victims were predominantly males $(\mathrm{n}=282 ; 80.3 \%)$ and farm workers $(n=211 ; 60.1 \%)$. With regard to the age range of the victims, the largest number of attacks was reported for individuals aged 50 years or above $(\mathrm{n}=102 ; 29.1 \%)$ when compared with the other ranges $(\mathrm{p}<0.05)$. The smallest number was observed for the range between 1 and 9 years $(n=17 ; 4.8 \%)$. The parts of the body mostly bitten were the feet $(\mathrm{n}=237 ; 67.5 \%)$ and the hands ( $\mathrm{n}=74 ; 21.1 \%)$. Snakes of the genus Bothrops were responsible for 265 snakebite cases (75.5\%), the genus Crotalus for 21 (6.0\%), Micrurus for $8(2.3 \%)$, and Lachesis for $2(0.6 \%)$. Successful cures predominated and only two deaths were reported (one involving Crotalus, in 2008, and the other involving Bothrops, in 2009). Concerning the time elapsed between attack and medical assistance, $180(51.3 \%)$ patients were attended within 1 to 3 hours and 60 (17.1\%) within 1 hour after being bitten. There was significant difference between the average number of patients assisted within 1 to 3 hours and those assisted up to 1 hour after being bitten $(\mathrm{p}<0.05)$. Serotherapy was applied in $330(94.0 \%)$ of the patients, while $14(4.0 \%)$ received no antivenom. Table 3 shows the clinical classification of the cases for each snake genus. Attacks by Bothrops were mostly classified as mild ( $\mathrm{n}=150$; $75.4 \%)$, by Crotalus as mild ( $\mathrm{n}=10)$, and by Micrurus as mild ( $\mathrm{n}=5 ; 2.5 \%)$. Of the two attacks by Lachesis, one was classified as moderate and one was not described.

\section{Discussion}

Previous studies have shown that most of snakebite cases in the state of Paraiba were clinically classified as moderate ${ }^{2}$. In the present study, the majority of cases were also classified as mild, confirming the results of Oliveira et al. ${ }^{1}$. Taken together, these results suggest that a change is occurring in the clinical classification of cases, in different regions of the state of Paraiba. Furthermore, the present study shows that most accidents occur in individuals over the age of 50 years. This result is different from those reported in other studies conducted in Paraíba ${ }^{9,10}$. The majority of the snakebite cases reported in the Cariri municipalities occurred in rural areas with people engaged in farm activities. The snake attacks occurred mostly from April to November, suggesting a seasonal distribution of these accidents in the region studied. This period coincides with the rainy season, when farm activities are more intense. The increased presence of workers in rural areas implies a greater probability of snake attacks, mainly because it can reduce that distance in which the animal feels safe from human aggression. The increased number of snakebite cases during the rainy period was also observed in other regions of the northeastern Bra$\mathrm{zil}^{14,15}$, as well as in the North ${ }^{16,17}$ and Midwestern of the country ${ }^{18}$. Likewise, studies on the epidemiology of snakebites in the Southeast ${ }^{18}$ and Midwerstern ${ }^{19,20}$ found a higher incidence of snakebite cases during the rainy period, which occurs from October to March in these regions. The relationship between snakebites, rainy season and farm labor reinforces the classification of these incidents as labor-associated accidents ${ }^{3,14}$. This situation generates strong medical, social and economic impacts in Brazil, especially in the Northeast, where the populations most exposed to snakes, generally living in smaller and poorer municipalities, are also those less assisted by the government ${ }^{21}$. The classification of snakebite cases as labor-associat- 
Table 2. Descriptive analyses of snakebite cases registered in the Cariri region, State of Paraíba, Brazil, from 2007 to 2010, characterizing the victims and the circumstances of the attacks $(n=351)$.

\begin{tabular}{|c|c|c|c|c|c|}
\hline \multirow{2}{*}{ Variables } & \multicolumn{4}{|c|}{ Year } & \multirow[b]{2}{*}{ Total } \\
\hline & 2007 & 2008 & 2009 & 2010 & \\
\hline \multicolumn{6}{|l|}{ Age group (years) } \\
\hline $1|-| 9$ & 4 & 6 & 2 & 5 & 17 \\
\hline $10|-| 19$ & 15 & 15 & 14 & 22 & 66 \\
\hline $20|-| 29$ & 12 & 10 & 15 & 14 & 51 \\
\hline $30 \quad|-| 39$ & 17 & 10 & 11 & 8 & 46 \\
\hline $40 \quad|-| 49$ & 20 & 10 & 16 & 23 & 69 \\
\hline$>50$ & 27 & 21 & 28 & 27 & $102^{*}$ \\
\hline Unknown & 0 & 0 & 0 & 0 & 0 \\
\hline Total per age group & 95 & 72 & 85 & 99 & 351 \\
\hline \multicolumn{6}{|l|}{ Gender } \\
\hline Male & 81 & 57 & 64 & 80 & 282 \\
\hline Female & 14 & 15 & 21 & 19 & 69 \\
\hline Total & 95 & 72 & 85 & 99 & 351 \\
\hline \multicolumn{6}{|l|}{ Work-related accident } \\
\hline Yes & 60 & 46 & 51 & 54 & 211 \\
\hline No & 25 & 23 & 28 & 31 & 107 \\
\hline Unknown & 10 & 3 & 6 & 14 & 33 \\
\hline \multicolumn{6}{|l|}{ Part of the body bitten } \\
\hline Forearm & 2 & 0 & 1 & 2 & 5 \\
\hline Hand & 23 & 12 & 16 & 23 & 74 \\
\hline Leg & 4 & 3 & 5 & 7 & 19 \\
\hline Foot & 56 & 54 & 62 & 65 & 237 \\
\hline Arm & 1 & 1 & 0 & 0 & 2 \\
\hline Head & 2 & 1 & 0 & 0 & 3 \\
\hline Unknown & 7 & 1 & 1 & 2 & 11 \\
\hline \multicolumn{6}{|l|}{ Antiserum } \\
\hline Yes & 89 & 63 & 84 & 94 & 330 \\
\hline No & 4 & 6 & 1 & 3 & 14 \\
\hline Unknown & 2 & 3 & 0 & 2 & 7 \\
\hline \multicolumn{6}{|c|}{ Time from bite until assistance (hours) } \\
\hline $0|-| 1$ & 8 & 14 & 18 & 20 & 60 \\
\hline $1|-| 3$ & 44 & 35 & 46 & 55 & $180^{* *}$ \\
\hline $3|-| 6$ & 15 & 13 & 13 & 11 & 52 \\
\hline $6|-| 12$ & 4 & 2 & 5 & 1 & 12 \\
\hline $12|-| 24$ & 1 & 2 & 0 & 3 & 6 \\
\hline Above 24 & 2 & 2 & 2 & 2 & 8 \\
\hline Unknown & 21 & 4 & 1 & 7 & 33 \\
\hline Total number of cases & 95 & 72 & 85 & 99 & 351 \\
\hline
\end{tabular}

" $\mathrm{p}<0.05$ significant in the relation to the individuals of other age ranges (Tukey Test). ${ }^{* *}<0.05$ significant in the relation to the patients assisted up to 1 hour after being bitten (Anova Test).

ed accidents is also reinforced when the frequencies of attacks are compared between men and women. In the current study, as well as in others found in the literature ${ }^{19,20}$, most victims were shown to be men, who predominate in non-domestic labor activities in rural areas, that is, where snake attacks are more common ${ }^{22}$. In terms of the age range of the victims, most of them were aged
50 years or older $(\mathrm{n}=102 ; 29.1 \%)$. This result reflects not also the aging of the Brazilian population, but also the expressive number of older people among rural workers ${ }^{23}$. A large number of snakebite cases was also observed among individuals between 40 and 49 years old $(n=69 ; 19.7 \%)$, which is the age range with the largest concentration of individuals engaged in farm labor ${ }^{24}$. These 
Table 3. Classification and evolution of snakebite cases in the Cariri region, State of Paraíba, Brazil, according to the snake genus, from 2007 to $2010(\mathrm{n}=351)$.

\begin{tabular}{|c|c|c|c|c|c|c|c|}
\hline \multirow{2}{*}{ Snake genus } & \multicolumn{4}{|c|}{ Clinical Classification of the Cases } & \multicolumn{2}{|c|}{ Evolution } & \multirow[b]{2}{*}{ Death } \\
\hline & Mild & Moderate & Severe & Unknown & Cured & Unknown & \\
\hline Bothrops spp. & 150 & 79 & 13 & 23 & 244 & 20 & 1 \\
\hline Crotalus spp. & 10 & 9 & 1 & 1 & 19 & 1 & 1 \\
\hline Micrurus spp. & 5 & 3 & 0 & 0 & 8 & 0 & 0 \\
\hline Lachesis spp. & 0 & 1 & 0 & 1 & 2 & 0 & 0 \\
\hline Unknown & 34 & 16 & 2 & 3 & 52 & 3 & 0 \\
\hline Total & 199 & 108 & 16 & 28 & 325 & 24 & 2 \\
\hline
\end{tabular}

findings contrast with other studies carried out in Brazil ${ }^{19}$. Lima et al. ${ }^{24}$ showed that most snakebite victims in the state of Minas Gerais were aged 10 to 19 years. Albuquerque et al. ${ }^{9}$ reported that snakebite victims in the state of the Paraíba were mostly aged between 30 and 39 years. Later studies also conducted in Paraíba reported that attacks were more frequent in the age ranges $10-29$ years ${ }^{25}$ and 11-20 years ${ }^{22}$. This discrepancy may be attributed to demographic and occupational differences between the diverse regions of the country, as well as to the engagement of younger people in farm labor in some of these regions, probably due to the need to increase family incomes.

In the current study, for the snakebite cases in which the genus was identified, the genus Bothrops was responsible for almost all of the cases (265 cases; $75.5 \%$ ) reported during the study period. This result is in accordance with other studies conducted in Brazil ${ }^{8,17}$ and in others country of Latin America ${ }^{26}$. The predominance of attacks by Bothrops may be attributed to the high diversity of species in this genus and to the fact that they are typically aggressive ${ }^{7}$, occupy many diverse habitats $^{7}$, are widely distributed in Brazil, and can be found in most ecosystems ${ }^{14}$. Snakes of the genera Crotalus, Micrurus and Lachesis accounted for $21(6.0 \%), 8(2.3 \%)$, and $2(0.6 \%)$ snakebite cases, respectively. Snakes of the genus Lachesis inhabit forest areas in the Amazon and Atlantic Forest biomes and humid forest enclaves in the northeastern Brazil ${ }^{3,14}$. Therefore, notifications of attacks by snakes of this genus in the dryland study area may indicate that medical records were incorrect on this point. The high number of cases in which the snake genus was not identified ( 55 cases; $15.7 \%$ ) corroborates this hypothesis, since it may be indicative of the lack of technical knowledge by both health workers (nurses and their helpers, pharmacists, doctors, and others) and general population, who are usually not able to recognize those characteristics important for identifying the snake genus. Additionally, in the northeastern Brazil the practice to take the offending snake to the health service center is uncommon, despite being extremely important for securely identifying the snake and indicating the correct antivenom.

In our series, most snakebite cases were clinically classified as mild (199 cases; $56.7 \%$ ) or moderate ( 108 cases; $30.8 \%$ ). These results are in agreement with other epidemiological studies conducted in Paraíba ${ }^{9,25}$. In contrast, studies carried out in other Brazilian regions showed higher incidences of moderate cases ${ }^{6}$. This divergence may be a result of differences in the venom components between species of Bothrops. With regard to attacks by Bothrops, most cases were classified as mild ( $\mathrm{n}$ $=150 ; 42.7 \%$ ); the number of cases classified as moderate $(\mathrm{n}=79 ; 22.5 \%)$ was also significant, and only a few cases were considered as severe $(n=13$, $3.7 \%$ ). The cases of attacks by Crotalus and $\mathrm{Mi}$ crurus were predominantly mild. However, it was also significant the snakebite cases by Crotalus classified as moderate $(n=9)$. For the association between clinical classification and genus of the snake, it was performed the Chi-square test. We obtained $\chi 2=17,497(\mathrm{p}$-value $=0.008)$ and it may suggest that the classification of the case is linked to the genus of the snake. Regarding the association between mortality and genus snake, we obtained $\div 2$ $=2556$ ( $\mathrm{p}$-value $=0465)$, suggesting that snakebite cases related to the different genera are not statistically significant, as to lethality. In this case, whereas the highest incidence of both genus, the risk of death in an attack by Crotalus (4\%) was 10 times higher than that by Bothrops (0.4\%). Most victims $(\mathrm{n}=180 ; 51.3 \%)$ received medical assistance up to 
3 hours after the attack, but there was a significant number of victims $(n=60 ; 17.1 \%)$ who were attended within $1 \mathrm{~h}$ after being bitten. Earlier studies undertaken in Brazil ${ }^{10,24}$ reported that more than $80 \%$ of the snakebite victims were attended within 6 hours after attack. The time elapsed between bite and medical assistance is of significant importance to the prognosis of the victim ${ }^{16}$, and smaller time gaps, better the chances of avoiding complications such as necrosis, compartment syndrome, and acute renal insufficiency ${ }^{14}$. In a high proportion of the hospital charts, there were no accounts of the clinical evolution of the patient $(n=24 ; 6.8 \%)$ or the time elapsed between bite and medical assistance $(\mathrm{n}=33 ; 9.4 \%)$. This observation demonstrates the precariousness of the regional health system, which usually has very few health workers, who, in turn, have little technical knowledge about snakebite envenomations. Additionally, the lack of information about clinical evolution of the cases may be indicative of a lack of clinical followup of the patients after initial serotherapy. Since this information is fundamental to the knowledge about snakebite treatments at local and regional levels ${ }^{27}$, the improvement in data collection procedures seems to be urgent. Despite all faults in Brazilian health system, the snakebite mortality rate was observed to be low in the study area $(0.0001 \%)$, as well as in other regions of Brazil ${ }^{3,14}$. The low frequency of severe cases $(n=16 ; 4.6 \%)$ may be the most probable cause of the reduced number of deaths observed in the current study. On the other hand, the lack of data about clinical severity in 28 patient records $(8.0 \%)$ suggests that the actual mortality rate might be higher. A possible severity in these cases might have required immediate transfer to better equipped hospitals, so that victims were not followed up in the health unit where they were initially attended. Early treatments, availability of antivenin, and the construction and maintenance of secondary roads increasing the access to rural areas are also important factors that help explain the low mortality rates of snakebite victims in the municipalities investigated.

The most frequent local manifestations were: pain $(n=286 ; 81.5 \%)$, edema $(n=218 ; 62.1 \%)$, ecchymosis $(n=26 ; 7.4 \%)$, paresthesia $(n=4$; $1.1 \%)$, headache $(\mathrm{n}=2 ; 0.6 \%)$, and necrosis $(\mathrm{n}=$ $5 ; 1.4 \%)$. The most frequent systemic clinical manifestations were: vasovagal $(\mathrm{n}=34 ; 9.7 \%)$, neurological $(\mathrm{n}=28 ; 8.0 \%)$, renal $(\mathrm{n}=16 ; 4.6 \%)$, myolytic $(\mathrm{n}=24,6.8 \%)$, and hemorrhagic $(\mathrm{n}=$ $32 ; 9.1 \%$ ). These clinical symptoms of snakebite envenomation were observed to be the same as those found in other studies carried out not only in the state of Paraíba ${ }^{9,25}$, but also in other regions of Brazil ${ }^{28,29}$. The body regions most frequently bitten were the feet and the hands, similarly to what was reported by other researchers in Brazil ${ }^{19}$, South Africa ${ }^{30}$ and Costa Rica ${ }^{26}$. These parts of the body are mostly bitten probably due to their greater exposure during field labor activities. This finding suggests that personal safety articles (such as boots, snake-guards, and gloves) are not regularly used by rural workers ${ }^{3}$, especially on farms that are poorly mechanized, during activities requiring the use of hoes and shovels, or during planting activities. Antivenom was administered to most victims $(\mathrm{n}=330 ; 94.0 \%)$, and the numbers of antivenom ampoules used in these treatments varied from 0 to 10 . In 14 cases $(4.0 \%)$, victims received no antivenom, probably due to the fact that it was not available in the Health Center at the time of medical assistance. The two cases that resulted in death occurred in the rural zone and involved males older than 50 years who were farm workers; they had both been bitten on the foot. The time elapsed between bite and their medical assistance was less than 3 hours. Both cases were classified as severe; eight ampoules of antivenom were administered to treat the attack by Bothrops and 10 to treat the one by Crotalus. The cause of the death of both accidents was not recorded. The two deaths occurred among patients who received medical attention within three hours after bite. This finding suggests that deaths may have occurred due to administration of inadequate dose of antivenom and/or the use of non-specific antivenom.

Various deficiencies were identified on the notification files, such as high proportions of cases in which the genus of the snake was not reported, the lack of accounts of the time of day when the accident occurred, the clinical evolution of the patient, and the time elapsed between bite and initial treatment. These deficiencies on the clinic charts may be related to the unusual high demands at the health centers, the lack of available time of members of the health team, or little number of workers at the health unit ${ }^{1}$. These situations should be emphasized once they are all common in health care centers in the northeastern Brazil, and will all contribute to the incomplete patient records. The small municipalities in the Northeast, especially those with less than 25,000 inhabitants and more distant from large urban centers, generally have few qualified health workers or staff able to collect proper information about snakebite cases. Treatments involving serious health problems and/or emergencies (e.g. 
snakebites) increase the chances of incompletely registering patient information, especially where health services have only minimum infrastructures. However, even under optimal situations, recording medical information is often set aside in Brazil, frequently resulting in records improperly filed and stored. This is common even in university hospitals, with many patient charts being poorly filled out and lacking necessary information ${ }^{31}$. To aggravate this situation, the curricula of university courses in medicine and nursing are almost always deficient in terms of instruction about attacks by poisonous animals as are considerations about the health of rural workers in university courses of agronomy and veterinary medicine ${ }^{22}$. Accordingly, a further understanding of the snakebite epidemiology in the northeastern Brazil seems to require better training for health workers and more adequate protocols for recording and filing victim's informa- tion. Without basic infrastructure and training, it will be difficult to gather precise information about health problems related to snakebite attacks in towns and villages in Brazil, the risks involved in these incidents, or the logistics of antivenom production and distribution.

This study may contribute towards a better comprehension of the ophidism in the state of Paraíba, thus representing a useful instrument for identifying the conditions that increase the risk of snake attacks in the northeastern Brazil. This knowledge may in turn provide a basis for the optimization of antivenom production and distribution, as well as for the improvement of the assistance to the victims. Additionally, a better understanding of ophidian problems in the northeastern Brazil may furnish important data for improving educational campaigns designed to prevent these types of attacks, as well as for preserving snakes.

\section{Collaborations}

ITG Targino, YACF Lopes and RM Barros worked in the survey of the literature, in the research and methodology. AA Vieira worked on statistical analysis of data and RS Leite worked on the conception and design the study, analysis and interpretation data, wrote the first version of the article.

\section{Acknowledgements}

This study was supported by the Instituto Nacional de Ciência e Tecnologia em Toxinas (INCTTOX). The authors are grateful to Solange Maimoni Gonçalves for the English review. 


\section{References}

1. Oliveira FN, Brito MT, Morais ICO, Fook SML, Albuquerque HN. Accidents caused by Bothrops and Bothropoides in the state of Paraiba: epidemiological and clinical aspects. Rev Soc Bras Med Tropical 2010; 43(6):662-667.

2. Gutiérrez JM, Higashi HG, Wen FH, Burnouf T. Strengthening antivenom production in Central and South American public laboratories: report of a workshop. Toxicon 2007; 49(1):30-35.

3. Theakston RDG, Warrell DA, Griffiths E. Report of a WHO workshop on the standardization and control of antivenoms. Toxicon 2003; 41(5):541-557.

4. Chippaux JP, Stock RP, Massougbodji A. Methodology of clinical studies dealing with the treatment of envenomation. Toxicon 2010; 55(7):1195-1212.

5. Lira-da-Silva RM, Mise YF, Brazil TK, Casais-eSilva LL, Carvalho FM. Morbimortalidade por ofidismo no nordeste do Brasil (1999-2003). Gaz Méd Bahia 2009; 79(Supl. 1):21-25.

6. Rosenfeld G. Symptomatology, pathology, and treatment of snakebite in South America. In: Bucherl W, Buckley EE, editors. Venomous animals and their venoms. New York: Acad Press; 1971.

7. Otero-Patinõ R. Epidemiological, clinical and therapeutic aspects of Bothrops asper bites. Toxicon 2009; 54(7):998-1011.

8. Gutiérrez JM, Theakston RDG, Warrell DA. Confronting the neglected problem of snake bite envenoming: The need for a global partnership. PLoS Med 2006; 3(6):727-731.

9. Albuquerque HN, Fernandes A, Albuquerque ICS. Snakebites in Paraíba, Brazil. J. Venom. Anim. Tox Incl. Tropical Dis 2005; 11(3):242-251.

10. Borges CC, Sadahiro M, Santos MC. Aspectos epidemiológicos e clínicos dos acidentes ofídicos ocorridos nos municípios do Estado do Amazonas. Rev Soc Bras Med Tropical 1999; 32(6):637-646.

11. Bochner R, Struchiner CJ. Epidemiologia dos acidentes ofídicos nos últimos 100 anos no Brasil: uma revisão. Cad Saude Publica 2003; 19(1):7-16.

12. Kouyoumdjian JA, Polizelli C, Lobo SMA, Guimarães SM. Acidentes ofídicos causados por Bothrops moojeni na região de São José do Rio Preto, São Paulo. Arq Bras Medicina 1990; 64(3):167-171.

13. Silva FG, Tavares-Neto J. Avaliação dos Prontuários Médicos de Hospitais de Ensino do Brasil. Rev Bras Edu Méd 2007; 31(2):113-126.

14. Pinho FMO, Pereira ID. Ofidismo. Rev Assoc Méd Brasileira 2001; 47(1):24-29.

15. Pinho FMA, Oliveira ES, Faleiros F. Acidente ofídico no Estado de Goiás. Rev Assoc Méd Brasileira 2004; 50(1):93-96.

16. Feliciano MLM, Melo RB. Atlas do estado da Paraí$b a$ - Informação para gestão do patrimônio natural. João Pessoa: SEPLAN, IDEME; 2003.

17. Feitosa RFG, Melo IMLA, Monteiro HSA. Epidemiologia dos acidentes por serpentes peçonhentas no estado do Ceará - Brasil. Rev Soc Bras Med Tropical 1997; 30(4):295-301.
18. Lemos JC, Almeida TD, Fook SML, Paiva AA, Simões MOS. Epidemiologia dos acidentes ofídicos notificados pelo Centro de Assistência e Informação Toxicológica de Campina Grande (Ceatox-CG), Paraíba. Rev Bras Epidemiologia 2009; 12(1):50-59.

19. Lima JS, Júnior HM, Martelli DRB, Silva MS, Carvalho SFG, Canela JR, Bonan PRF. Perfil dos acidentes ofídicos no norte do Estado de Minas Gerais, Brasil. Rev Soc Bras Med Tropical 2009; 42(5):561-564.

20. Instituto Brasileiro de Geografia a Estatística (IBGE). [homepage on the Internet]. [cited 2010 Nov 22]. Available from: http://www.ibge.gov.br/home/

21. Fernández P, Gutiérrez JM. Mortality due to snakebite envenomation in Costa Rica (1993-2006). Toxicon 2008; 52(3):530-533.

22. Oliveira HFA, Leite RS, Costa CF. Aspectos clínicos-epidemiológicos de acidentes com serpentes peçonhentas no município de Cuité, Paraíba, Brasil. Gaz Méd Bahia 2011; 81(1):14-19.

23. Rojas CA, Gonçalves MR, Almeida Santos SM, 2007. Epidemiologia dos acidentes ofídicos na região noroeste do estado de São Paulo, Brasil. Revista Brasileira de Saúde 2007; 8(3):193-204.

24. Moreira ERF. Mesorregiões e microrregiões da Paraí$b a$ : Delimitação e caracterização. João Pessoa: Gasp; 1989.

25. Blaylock R. Epidemiology of snakebite in Eshowe, KwaZulu-Natal, South Africa. Toxicon 2004; 43(2): 159-166.

26. Brasil. Ministério da Saúde (MS). Manual de diagnóstico e tratamento de acidentes por animais peçonhentos. 2a Edição. Brasília: Fundação Nacional de Saúde; 2001.

27. Silva CJ, Jorge MT, Ribeiro LA. Epidemiology of snakebite in a central region of Brazil. Toxicon 2003; 41(2):251-255.

28. Mise YF, Lira-da-Silva RM, Carvalho FM. Envenenamento por serpentes do gênero Bothrops no estado da Bahia: aspectos epidemiológicos e clínicos. Rev Soc Bras Med Tropical 2007; 40(5):569-573.

29. Waldez F, Vogt RC. Aspectos ecológicos e epidemiológicos de acidentes ofídicos em comunidades ribeirinhas do baixo rio Purus, Amazonas, Brasil. Acta Amaz. 2009; 39(3):681-696.

30. Albuquerque HN, Costa TBG, Cavalcanti MLF. Estudo dos Acidentes Ofídicos Provocados por Serpentes do Gênero Bothrops Notificados no Estado da Paraíba. Rev Bio Cien Terra 2004; 5(1):1-7.

31. Lira-da-Silva RM, Mise YF, Casais-e-Silva LL, Ulloa J, Hamdan B, Brasil TK. Serpentes de importância médica do nordeste do Brasil. Gaz Méd Bahia 2009; 79(1):7-20.

Artigo apresentado em 05/06/2012

Aprovado em 23/08/2012

Versão final apresentada em 07/09/2012 